ORIGINAL ARTICLE

\title{
ASYMPTOMATIC URINARY TRACT INFECTION BY PROTEUS MIRABILIS IN RHEUMATOID ARTHRITIS PATIENTS
}

\section{Laila Mostafa AL Kady, Mirvat Abd El Hamid El Toukhy, Maher Abd El Rahman El Shafie, Heba Abd El Aziz Mohammed, Nagwa Ibrahim Mohammed Saber*.}

\section{Medical Microbiology \& Immunology Department, Rheumatology and Rehabilitation Department, Faculty of Medicine, Zagazig University, Zagazig, Egypt}

${ }^{*}$ Corresponding author :

Nagwa Ibrahim Mohammed

Saber

Medical Microbiology \&

Immunology Department,

Faculty of medicine

,Zagazig university

Mohamed.sakr@bue.edu.eg

Submit Date 2019-03-25

Revise Date 2019-04-17

Accept Date 2019-04-21

\section{ABSTRACT}

Background: Proteus mirabilis is thought to contribute in rheumatoid arthritis (RA) development in susceptible individuals through molecular mimicry mechanism. This study was detecting the prevalence of asymptomatic bacteriuria (ABU) caused by Proteus mirabilis in RA patients to shed light on its rule in RA pathogenesis.

Methods: This work has been conducted in medical Microbiology and Immunology Department and Rheumatology and Rehabitilation Department, Faculty of Medicine, Zagazig University, during the period from May 2017 to May 2018 over a period of 12 months. This study is a case control included 70 RA patients (66 females and 4 males), with age ranged from 25 to 65 years, and 70 healthy controls (67 females and 3 males), with age ranged from 24 to 65 years. Two consecutive urine samples one week interval were collected from each participant for urine count and culture. Blood samples were collected from each participant for detection the level of $\operatorname{IgG}$ antibodies against both Proteus mirabilis and E. coli (the most frequent isolated organism from the RA urine) by homely prepared ELISA.

Results: The ABU was detected in $(40 \%)$ of RA patients and in $(4.3 \%)$ of healthy controls. The most common isolated organisms were E. coli (50\%) followed by Proteus mirabilis (25\%). A significant difference between both studied groups regarding IgG antibodies levels against Proteus mirabilis was detected $(\mathrm{P}<0.001)$. No significant difference was observed between both studied groups regarding IgG antibodies levels against $E$. coli $(\mathrm{P}=0.902)$. Significant positive correlation was found between Proteus mirabilis IgG antibodies levels and the levels of ESR and CRP in RA patients.

In conclusion: Proteus mirabilis seems to have a role in RA development.

Keywords: Rheumatoid arthritis, Proteus mirabilis, asymptomatic bacteriuria, cross reactivity.

\section{INTRODUCTION}

$\mathrm{T}$ he exact etiology of RA is not clear but medical evidences suggest that it develops frequently in individuals with inherited genetic risk factors after their exposure to environmental triggers. There are many environmental risk factors, including exposure to infections, hormones, smoking and dietary factors [1]. 
Numerous studies have shown the clinical association between infection and RA. Infection is often detected in RA early stage and can precede the occurrence of clinical arthritis which suggests that infection contributes to the initiation and exaggeration of RA[2,3].

Proteus mirabilis is thought to contribute in RA development in susceptible individuals through molecular mimicry mechanism. Specifically, molecular similarities have been observed between the ESRRAL amino acid sequence, which is presented in $P$. mirabilis haemolysin and the EQRRAA sequence which is presented in the shared epitope of the RA-linked HLADR molecules. Also molecular similarity has been observed between IRRET amino acid sequence which is presented in $P$. mirabilis urease enzyme and the LRREI amino acid sequence which is presented in type XI collagen [4].

Consequently, repeated infections with $P$. mirabilis will result in the production of high titers of bacterial antibodies. The binding of these antibodies to the cross reactive self antigens will trigger a cascade of inflammatory responses which leads to the production of various chemokines and cytokines leading to a local inflammation with or without systemic effects. In addition, such activation may have a bystander effect on other immune cells, including $\mathrm{T}$ lymphocytes, which might result in further enhancement of the inflammatory immune responses with the development of arthritis and the systemic features of this disease[5,6].

\section{METHODS}

\section{Study design}

A case control study included 70 RA patients and 70 healthy controls was carried out during the period from May 2017 to May 2018 over a period of 12 months. This study was performed in Medical Microbiology \& Immunology and Rheumatology \& Rehabitilation Departments, Faculty of Medicine, Zagazig University Hospitals. RA patients were diagnosed according to 2010 ACR/EULAR RA classification criteria[7].

Sample size: assuming that percentage of Proteus mirabilis in rheumatoid arthritis patients and in control groups is (48\%vs14\%)[8]. (respectively so sample size is calculated by Epi Info 6 to be 140 cases ( 70 cases in each group) with confidence level $95 \%$ and power of test $80 \%$.

Ethical consideration: All procedures followed were in accordance with the ethical standards of the responsible committee on human experimentation (institutional and national) and with the Helsinki Declaration of 1975, as revised in 2000 [9]. Institutional Review Board (IRB) of the Faculty of Medicine, Zagazig University approved the study protocol. An informed consent was obtained from all participants of this study and they were told about the aim of the study, and were informed that the data would be used for scientific purposes only.

The following laboratory procedures were performed for the collected specimens including; urine and blood:

Urine samples processing: Two consecutive urine samples "one week interval" were collected from each participant and examined for urine count and bacterial culture. (ABU is defined as a mid-stream urine showing growth of uropathogenic bacteria $\geq 10^{5}$ $\mathrm{CFU} / \mathrm{ml}$ in two consecutive samples in women and in a single sample in men[10]. Urine count was done on CLED agar, a count of $10^{5}$ or more was considered significant. All the isolated organisms were identified by gram staining and biochemical reactions.

Homely prepared ELISA: for detection of Proteus mirabilis IgG and E. coli antibodies in the serum of the study subjects.

- Preparation of the antigen: The preserved cultures of Proteus mirabilis on brain heart infusion (BHI) agar slants were sub cultured in BHI broth. After 24 hours incubation, the cultures were inoculated onto freshly prepared plates of BHI agar containing 1:800 phenol and incubated 24 hours, the growth on the plates was scraped gently with a sterile loop, suspended in $3 \mathrm{ml}$ sterile normal saline $(0.9 \% \mathrm{w} / \mathrm{v})$. Then the organism was heat killed by maintaining the culture suspension in a heater at $60^{\circ} \mathrm{C}$ for 30 minutes. The culture suspension was then centrifuged at 3000 RPM for 15 minutes. The supernatant was discarded and the pellet was washed with $400 \mu \mathrm{l}$ of PBS-T for 3 times. 
After the third wash, carbonate-bicarbonate buffer was added to the pellet slowly, and the turbidity was adjusted to $4 \mathrm{McFarland}$ turbidity standard tubes.

Coating the ELISA plates with the tested microbial antigens: $100 \mu 1$ of the prepared antigen suspension was added to each well of ELISA plate. The plate was covered with aluminum foil and incubated at $37^{\circ} \mathrm{C}$ for 3 hours for sensitization. The sensitized plate was then kept at $4^{\circ} \mathrm{C}$ over night. Each well was aspirated and washed; the process was repeated three times with wash buffer $(400 \mu \mathrm{l}$ of PBS -T). Blocking was done with $150 \mu \mathrm{l}$ of $1 \%$ Bovine serum albumin solution and incubating the plate at $37^{\circ} \mathrm{C}$ for 2 hours. The plate was again washed 3 times.

ELISA steps: Serum samples were diluted 1:10 using PBS then added to the corresponding wells in duplicate and incubated at $37^{\circ} \mathrm{C}$ for 90 minutes. The wells were washed 3 times with PBS-T fluid. 100 $\mu l$ of the Horse Radish Peroxidase conjugated with anti-human $\operatorname{IgG}$ was added to each well. The wells were incubated at $37^{\circ} \mathrm{C}$ for 90 minutes and washed 3 times. The Chromogenic substrate $(100 \mu \mathrm{l})$ was added. The plate was incubated at $37^{\circ} \mathrm{C}$ for 20 minutes away from the light. $50 \mu \mathrm{l}$ of the stop solution was added to each well. .Within 30 minutes, the optical density (OD) of each well was determined using ELISA reader (Stat fax 303 plus) set to $492 \mathrm{~nm}$. The mean OD of each duplicate was calculated.

\section{Statistical analysis}

The collected data were computerized and statistically analyzed using SPSS program (Statistical Package for Social)

\section{RESULTS}

This study has been conducted on two groups, the case group which includes 70 RA patients and the control group which includes 70 apparently healthy volunteers during the period from May 2017 to May 2018.

Science) version 20 (11). Qualitative data were represented as frequencies and relative percentages. Categorical data were compared using Chi-square test.

Table (1) demonstrated that twenty eight out of 70 investigated case group (40\%) have ABU in comparison to 3 out of 70 investigated control group (4.3\%). There is highly statistically significant difference between both studied groups regarding the frequency of $\mathrm{ABU}(\mathrm{P}<0.001)$.

Table (2) demonstrated that in the case group $(50 \%)$ of isolated organisms were E. coli, (25\%) were Proteus mirabilis, (14.3\%) were Enterococci, and (10.7\%) were Staph saprophyticus, while in the control group (66.7\%) were E. coli and (33.3\%) were Staph saprophyticus.

Table (3) demonstrated that there is highly statistically significant difference between both studied groups regarding Proteus mirabilis IgG antibodies levels $(\mathrm{P}<0.001)$.

Table (4) demonstrated that there is no statistically significant difference between both studied groups regarding E. coli $\mathrm{IgG}$ antibodies levels, although the level of $E$. coli $\mathrm{IgG}$ antibodies among the case group $(0.55 \pm$ $0.13)$ is higher than this of the control group $(0.53 \pm 0.06)(\mathrm{P}<=0.902)$.

Table (5) demonstrated that there is a statistically significant difference between RA patients regarding Proteus mirabilis $\mathrm{IgG}$ antibodies levels. The highest level of Proteus mirabilis $\mathrm{IgG}$ antibody was detected in RA patients with Proteus mirabilis ABU $(\mathrm{P}<$ $0.045)$.

Table (6) demonstrated that there is statistically significant positive correlation between levels of Proteus mirabilis IgG antibodies and the levels of ESR and CRP. 
Table (1): Frequency distribution of ABU among studied groups

\begin{tabular}{|c|c|c|c|c|c|c|}
\hline \multirow[t]{2}{*}{ Groups } & \multicolumn{2}{|c|}{$\begin{array}{c}\text { Case } \\
\text { group } \\
(70)\end{array}$} & \multicolumn{2}{|c|}{$\begin{array}{c}\text { Control group } \\
\text { (70) }\end{array}$} & \multirow[t]{2}{*}{ Test } & \multirow[t]{2}{*}{$\mathbf{P}$} \\
\hline & $\mathbf{N}$ & $\%$ & $\mathbf{N}$ & $\%$ & & \\
\hline Significant bacteriuria & 28 & 40 & 3 & 4.3 & \multirow[t]{2}{*}{ Fisher } & \multirow[t]{2}{*}{$<0.001 * *$} \\
\hline $\begin{array}{c}\text { Non-significant } \\
\text { Bacteriuria }\end{array}$ & 42 & 60 & 67 & 95.7 & & \\
\hline
\end{tabular}

Table( 2): ABU causative organisms in studied groups:

\begin{tabular}{|c|c|c|c|c|}
\hline Isolated organisms & \multicolumn{2}{|c|}{$\begin{array}{c}\text { Case group } \\
\text { (NPI=28) }\end{array}$} & \multicolumn{2}{|c|}{$\begin{array}{c}\text { Control group } \\
\text { (NPI=3) }\end{array}$} \\
\hline E. coli & N & \% & N & $\%$ \\
\hline Proteus mirabilis & 14 & 50 & 2 & 66.7 \\
\hline Enterococci & 7 & 25 & 0 & 0 \\
\hline Staph. Saprophyticus & 4 & 14.3 & 0 & 0 \\
\hline
\end{tabular}

Table (3): P. mirabilis IgG antibodies among studied groups.

\begin{tabular}{|c|c|c|c|c|}
\hline Variable & $\begin{array}{c}\text { Case } \\
\text { group }(\mathbf{N}=70)\end{array}$ & $\begin{array}{c}\text { Control } \\
\text { group }(\mathbf{N}=70)\end{array}$ & t test & P \\
\hline $\begin{array}{c}\text { Proteus mirabilis } \text { IgG: } \\
\text { Mean OD } \pm \text { SD }\end{array}$ & $1.35 \pm 0.31$ & $0.41 \pm 0.08$ & 10.214 & $<0.001 * *$ \\
Range & $0.654-1.76$ & $0.301-0.567$ & & \\
\hline
\end{tabular}

Table( 4): $E$. coli IgG antibodies among studied groups:

\begin{tabular}{|c|c|c|c|c|}
\hline Variable & $\begin{array}{c}\text { Case group } \\
(\mathbf{N}=\mathbf{7 0})\end{array}$ & $\begin{array}{c}\text { Control group } \\
(\mathbf{N}=70)\end{array}$ & t test & $\mathbf{P}$ \\
\hline E.coli IgG: & & & & \\
\hline $\begin{array}{c}\text { Mean OD } \pm \text { SD } \\
\text { Range }\end{array}$ & $0.55 \pm 0.13$ & $0.53 \pm 0.06$ & 0.123 & 0.902 \\
\hline
\end{tabular}


Table (5): Relation between Proteus mirabilis ABU and levels of Proteus mirabilis IgG antibodies in the case group:

\begin{tabular}{|l|l|l|l|}
\hline Case group & $\begin{array}{l}\text { Proteus mirabilis IgG } \\
\text { Antibodies Mean OD } \pm \text { SD }\end{array}$ & t test & P \\
\hline $\begin{array}{l}\text { Patients with Proteus } \\
\text { mirabilis ABU (N=7) }\end{array}$ & $1.62 \pm 0.14$ & 1.959 & $0.045^{*}$ \\
\hline $\begin{array}{l}\text { Patients without Proteus } \\
\text { mirabilis ABU }(\mathbf{N}=63)\end{array}$ & $1.23 \pm 0.3$ & & \\
\hline
\end{tabular}

Table (6): Correlation between Proteus mirabilis IgG antibodies levels, RA duration and the acute phase reactants in in the case group:

\begin{tabular}{|c|c|c|}
\hline \multirow{2}{*}{ Variable } & \multicolumn{2}{|c|}{ Proteus mirabilis IgG antibodies levels } \\
\cline { 2 - 3 } & $\mathbf{R}$ & $\mathbf{P}$ \\
\hline ESR $(\mathrm{mm} / \mathrm{hr})$ & 0.906 & $<0.001 * *$ \\
\hline $\mathrm{CRP}(\mathrm{mg} / \mathrm{dl})$ & 0.847 & $<0.001 * *$ \\
\hline
\end{tabular}

\section{DISCUSSION}

There are numerous ways in which infection can lead to autoimmune diseases, including the initiation of tissue damage leading to the exposure of previously hidden self-antigens or the elaboration of super antigens. Also it has been proposed that similarities in antigenic proteins between infecting pathogens and host tissues may result in immune response against the host tissues [12]. As regards $P$. mirabilis various genetic, microbiological, molecular and immunological studies carried out by independent research groups support its role in RA pathogenesis through recurrent subclinical Urinary tract infection[13].

A case control study was designed and the study participants were classified into 2 groups: a case group which included seventy RA patients (66 females and 4 males), with age ranged from 25 to 65 years and a control group which included seventy apparently healthy volunteers (67 females and 3 males), with age ranged from 24 to 65 years, the two groups were almost matched in sex and age. Our results showed that there was a highly statistically significant difference between both studied groups regarding ABU frequency. It was detected in $(40 \%)$ of the urine samples from RA patients in comparison to $(4.3 \%)$ in the healthy control. In our study, E. coli was the most common predominant organisms $(50 \%)$ in RA patients and $(66.7 \%)$ in the healthy control. $P$. mirabilis was the second most common isolated organism after E. coli. It was isolated from $(25 \%)$ of the urine samples of RA patients while it was not isolated from the control group. Our result was nearly in agreement with Senior et al who reported slightly elevated rate for isolation of $P$. mirabilis (33\%) from the urine of 76 RA patients in comparison to (4\%) from the urine of 48 gender-matched healthy individuals[13]. On the contrary, Georgiadou et al did not find any significant differences between RA patients and healthy control regarding $\mathrm{ABU}$ frequency[14]. On studying the association between P. mirabilis $\operatorname{Ig} G$ antibodies and $R A$ by Home made ELISA, we used crude $P$. mirabilis antigen preparation. We recorded a highly significant difference between both study groups. The mean OD in RA was (1.35 $\pm 0.31)$ versus $(0.41 \pm 0.08)$ in the control group. Also Raj Kumar et al reported that the mean antibody titre against $P$. mirabilis in RA was $(1.74 \pm 0.6)$ and this was significantly higher than in the control group $(0.13 \pm 0.3)$ [8].

On the other hand, Christopoulos et al used three synthetic amino acid peptides. Each one of them contained a homologous amino acid sequence with $P$. mirabilis enzyme [12]. They found that RA patients presented significant elevated levels of antibodies against these synthetic peptides when compared to healthy controls. Based on these results, both home 
made ELISA using crude antigens and synthetic peptides reported significant increase in the levels of $P$. mirabilis $\operatorname{IgG}$ antibodies in RA patients in comparison to the healthy controls. However, the use of these synthetic amino acid peptides could help in identification the exact cross-reactive epitopes between human tissue antigens and $P$. mirabilis. Production of vaccine lacking these cross-reactive epitopes will be possible. This approach may be effective for susceptible individuals to resist RA development. However, the use of these synthetic amino acid peptides was expensive and not available in our study so we use crude antigen preparation. In the present study, $E$. coli was the most frequent isolated organism from RA patients $(50 \%)$, so it was indicated to evaluate its association with RA (if any) in comparison to Proteus mirabilis. We found no significant differences between both study groups regarding $E$. coli $\mathrm{IgG}$ antibodies.

In the current study, the highest levels of of $P$. mirabilis $\operatorname{IgG}$ antibodies were detected in patients with $P$. mirabilis ABU. The mean $\mathrm{OD} \pm \mathrm{SD}$ of these antibodies was $(1.62 \pm 0.14)$ versus $(1.23 \pm 0.3)$ in other RA patients.

Our results showed a significant positive correlation between $P$. mirabilis IgG antibodies levels and the levels of the ESR and CRP in RA patients. It is in agreement with Rashid and Ebringer who reported the same results (15). The elevation of ESR and CRP levels is usually secondary to the result of immunological binding between $P$. mirabilis antibodies presenting in high titres and the cross-reactive HLA epitopes in synovial tissues, which leads to the activation of complements and other inflammatory cascades.

Limitation of this study: already synthesized ELISA was not available so we performed homely prepared ELISA. Also synthetic peptides were not available so we used crude antigens.

\section{CONCLUSION}

Proteus mirabilis seems to have a role in RA development. So we recommend carrying further studies using synthetic peptides for detection of the cross reactive epitopes between Proteus mirabilis and human tissue antigens which will help in production of
Proteus mirabilis vaccine lacking its cross reactive epitopes with human tissue antigens as a new strategy for RA eradication.

\section{Declaration of interest}

The authors report no conflicts of interest. The authors alone are responsible for the content and writing of the paper.

Funding information: None declared

\section{REFERENCES}

1- Ebringer A., Rashid T. and Wilson C. Rheumatoid arthritis, Proteus, anti-CCP antibodies and Karl Popper. Autoimm Rev. 2010; 9:216-223.

2- Song Li., Yangsheng Y. And Yinshi Y. Microbial infection and rheumatoid arthritis. J Clin Cell Immunol. 2013; 4(6): 174.

3- Pretorius E., Akeredolu O.O., Soma P. and Kell D.B. Major involvement of bacterial components in rheumatoid arthritis and its accompanying oxidative stress, systemic inflammation and hypercoagulability. Experimental Biology and Medicine. 2017; 242(4):355-373.

4- Ebringer $A$ and Rashid T. Rheumatoid arthritis is an autoimmune disease triggered by Proteus urinary tract infection. Clinical \& Developmental Immunology. 2006; 13(1): 41-48.

5- Guilherme L., Köhler K.F., Postol E. and Kalil J. Genes, autoimmunity and pathogenesis of rheumatic heart disease. Annals of Pediatric Cardiology. 2011; 4(1):13-21.

6- Wilson C., Rashid T., Tiwana H., Beyan H., Hughes L., Bansal S. et al. Cytotoxicity responses to peptide antigens in rheumatoid arthritis and ankylosing spondylitis. J Rheumatol. 2003; 30: 972-978.

7- Aletaha D., Neogi T., Silman A. J., Funovits J., Felson D.T., Burmester G.R.et al. 2010 rheumatoid arthritis classification criteria: an American College of Rheumatology/European League Against Rheumatism collaborative initiative. Ann. Rheum. Dis. 2010; 69 (9): 1580-1588.

8- Raj Kumar H.R.V., Devaki R. and Kandi V. Evaluation of anti-bacterial IgG antibodies among rheumatoid arthritis and non rheumatoid arthritis patients with special reference to anti Proteus antibodies. International Journal of Research in Medical Sciences. 2016; 4(2):628-632.

9- World Medical Association Declaration of Helsinki Ethical Principles for Medical Research Involving Human Subjects: Bull. 
World Health Organ. Epub, 2001;74:373374.

Available at:

https://www.ncbi.nlm.nih.gov/pubmed/11357 217.

10- Smelov V. Naber $K$. and Bjerklund Johansen T.E. Improved Classification of Urinary Tract Infection: Future Considerations European Urology Supplements. 2016; 15 (4), $71-80$.

11- IBM Corp. IBM SPSS Statistic for windows, version 22.0.Armonk, NY 2013; IBM Corp.

12- Christopoulos G., Christopoulou V., Routsias J.G. Babionitakis A. Antoniadis C. and Vaiopoulos G. Greek rheumatoid arthritis patients have elevated levels of antibodies against antigens from Proteus mirabilis. clin rheumatol. 2017; 35:1-9.
13- Senior B.W., Anderson G.A. and Morley K.D. Evidence that patients with rheumatoid arthritis have asymptomatic Bnon significant $^{\wedge}$ Proteus mirabilis bacteriuria more frequently than healthy controls. J Infect. 1999; 38:99-106.

14- Georgiadou S. P., Gamaletsou M. N., Mpanaka I. Vlachou A., Goules A.V., Ziogas D. C. et al. Asymptomatic Bacteriuria in Women With Autoimmune Rheumatic Disease: Prevalence, Risk Factors, and Clinical Significance. Clinical Infectious Diseases. 2014; 60(6): 868-874.

15- Rashid T. and Ebringer A. Rheumatoid arthritis is linked to Proteus the evidence. Clin Rheumatol. 2007; 26: 1036-1043.

To Cite This Article: Laila MA, Mirvat AE, Maher AE, Heba AM, Nagwa IM.Asymptomatic Urinary Tract Infection By Proteus Mirabilis In Rheumatoid Arthritis Patients.ZUMJ 2019;25(6);928-934.DOi:

10.21608/zumj.2019.10802.11360. 